\title{
THE FOREIGN LANGUAGE INFLUENCE IN THE PROCESS OF SHOP NAMING
}

\author{
Gülsen Danacı
}

\begin{abstract}
This study has been carried out for the purpose of determining to what extent foreign languages are used in shop signs and which factors are effective in the process of selecting name for workplaces. For this purpose, data have been collected from 204 shop owners in total comprised of two different regions of Ankara representing two different social structure of Ankara which are Vatan Street in Sincan and Tunall Hilmi Street in Çankaya and for the data collecting, a questionnaire consisting of 6 questions related to the research questions has been administered to 118 shop owners in Vatan Street in Sincan and 86 shop owners in Tunall Hilmi Street in Çankaya and final data obtained at the end of the survey are appraised and interpreted in the light of the research questions through calculating the frequencies and percentages. It has been found out that the proportion of foreign language usage in work-place signs is higher in Tunalı Hilmi Street than in Vatan Street. It has been inferred from the findings that the preference of shop names varies according to the socioeconomic and socio-cultural background of the shop owners.
\end{abstract}

Key words: Sociolinguistics, shop naming, work place signs.

\section{DÜKKAN İSIMLENDIRME SÜRECINDE YABANCI DİL ETKISİ}

$\ddot{O}_{z e t}$

Bu çalışma dükkan isimlerindeki yabancı dil kullanımının ne boyutta olduğunu ve isim verme sürecinde hangi faktörlerin etkili olduğunu saptamak amcıyla yapılmıştır. Bu amaçla veri, Ankara'nın iki ayrı sosyal yapıya sahip semtini temsil eden iki ayr caddeden(Vatan Caddesi, Sincan; Tunalı Hilmi, Çankaya) toplanmıştır. Veri toplama amacıyla araştırmacı tarafindan geliştirilen ankete toplam 204 işyeri sahibi katılmıştır. Araştırma sorularıla ilişkili 6 soru içeren anket Sincan'da 118 Çankaya'da 86 işyeri sahibine uygulanmıştır. Araştırmanın sonunda elde edilen veriler araştırma soruları doğrultusunda değerlendirilmiştir ve yorumlanmıştır. Bu değerlendirmeler sonucunda Tunalı Hilmi Caddesi'ndeki tabelalarda yabancı dil kullanım oranının Vatan Caddesindekilere oranla daha yüksek olduğu saptanmıştır. Elde edilen bulgular ise işyeri isimleri tercihinin işyeri sahibinin sosyo-ekonomik ve sosyo-kültürel düzeyine göre değiştiğini göstermiştir. 


\section{INTRODUCTION}

People have to communicate in order to explain their feelings and ideas, or understand the things that others convey since the human is social animate. Language is the most basic way of communication, since it covers many social and cultural elements. For this reason it is open to change. 'Everything rolls on; nothing stays still' claimed the ancient Greek philosopher Heraclitus in the sixth century B.C. Language, like everything else, gradually transforms itself over centuries. There is nothing surprising in this. In a world where humans grow old, tad poles change into frogs, milk turns into cheese, it would be strange if language alone rewarded unaltered (Aitchison, 1991:4). As the famous Swiss linguist Ferdinand de Saussure noted: 'Time changes all things. There is no reason why language should escape this universal law' (Aitchison qtd in Saussure 1915/1998:3).

It is needed to know considerably more about language change, how it happens, when it happens, who initiates it and possible reasons for its occurrence in order to understand language change process. Also people have speculated about the causes of language change. There are several different causative factors at work. That is, language change is likely due to combination of social factors beside linguistic ones. In this study, it has only been dealt with the sociolinguistic triggers such as foreign influence.

Foreign elements in a language trigger change in language. The spread of foreign elements usage in language is essentially a social phenomenon which reflects the social situation. For instance, in Turkish, due to the increasing language relations between some European languages such as German, French and especially English, foreign elements are widely seen. English which functions as a world language in almost every field of life due to its being an instrument of universal communication (König, 1991 and Akalın, 2000). When people learn a new language, they unintentionally impose some of sound patterns and to a lower extent syntax. But people mainly pick up the words of the language they are learning and add their existing language. This change of language always exists however it is realized too slowly to be noticed by the people. To illustrate the situation, the names of the hotels, trade marks of the products, the words in advertisements, etc are of the foreign origin. As understood from the examples, this kind of usage is more frequently seen in the fields related to the economy. In economy, using foreign trade marks has become so prestigious that any foreign trade mark started to be regarded as a demonstrator of better service and high quality of product (Özyıldırım, 2001).

Therefore, shop owners in the centre of the trade and industry have been choosing foreign-origin names recently for their work-places. This situation reached level beyond imagination. Foreign names are preferred by the shop owners in the remotest village and in the remotest region in Turkey. It can be inferred that the bigger the city, the less Turkish 
words are given to shop names . However, there are situations that necessitate the diversity of job and work-place variations. In this diversity, job owners give names to their shops according to their goals, principles and their establishment requirements in order to differentiate both the type of the job and work-places doing the same kind of job. In the same way with the language change, the choices of names change.

Names belong to society as they do to persons. They are one of the units of cultural presence of society (Duman, 2002 and Yurttaş, 2005). In this context, sociolinguistics, a branch of linguistics, studies this relationship between language and society. (Wray, Allison, Kate Trott, Aileen Bloomer, 2002:88).

In the following part, examples of sociolinguistic studies have been given some of which are directly related to this study while some are indirectly related. But all of them have same aim: foreign influence on language and the extent of this influence.

\section{Literature Review}

According to the observations the foreign elements in Turkish denote a decline. Yüce (2000) states that the percentage of foreign words, especially Western-origin words, in the dictionaries prepared by Turkish Language Institution (TDK) increased from the dictionary published in 1969 to the dictionary published in 1998.

In this increase also the dense relations between other countries learning new languages, the mass media and technological developments are also influential. Via these sources new words are added to dictionaries (Aydoğan, 2001). While some of these words are necessary to enrich the vocabulary of Turkish, some are unnecessary since there already exists Turkish words that meet the meaning of the word borrowed. On the other hand, some words may be functional in Turkish and could contribute to Turkish as a result of the qualitative transfer rather than quantitative transfer which may be called 'artificial borrowing'. (Osam, 1997). This wide use of foreign words in social life has given rise to a new trend: giving foreign names to shops, trade marks, streets and products. This list can further be extended. For example, Kansas, Manhattan, Florida, Dallas, Gloria, Royal, Boston are the names of a series of an armchair produced by Turks. Grand Prestige, Florioum, Mare Vista, Ideman Beach Club are the names of Turkish hotels. (Aydoğan, 2001)

There are many different reasons of the interest to foreign words. Language learning is always given importance. Another development which harms language is in the field of industry and trade. The producers whose business reaches the world markets have recently started to give foreign names to their products (Aydoğan, 1991). Similar situation is seen in shop names as well.

Özyıldırım (2001) states that the foreign names are given to the shops as a result of the exchange of information and technology, and the interaction between languages and cultures. 


\section{Hypothesis}

In the light of the findings above, it is seen that generally foreign words are preferred in work-places signs. Then, whether the shop owners select the names at random or according to a definite target during the naming process has been researched. According to this main goal, the answers of the questions below have been given at the end of the research:

1. In the preference of the shop names, is the place of the shop effective?

2. In the preference of the shop names, is the educational background of the shop owner effective?

3. In the preference of the shop owners, is the gender of the shop owner effective?

4. In which level foreign language is influential?

- Lexical

- Syntactical

- Phonological

\section{METHOD}

\section{Subjects}

In this study 204 shop signs have been used in total. 86 of these have been picked up in Tunalı Hilmi Street in Çankaya, and 118 of these have been picked up in Vatan Street in Sincan. The questionnaire was given to all shop owners who voluntarily filled the questionnaire. The ones who refused to answered the questions in the questionnaire have been excluded from the research. The shops were also selected in connection with the research goals. Vatan Street in Sincan and Tunalı Hilmi Street in Çankaya were chosen to study. The former was selected owing to its being a representative of the people who have lower income, lower educational background and who constitute more conservative part of Ankara. The latter was selected due to its being a representative of the people who have higher income, higher educational background and who constitute a more modern part of Ankara. These are the streets on which the trade is centered and work-places are densely located. This dense structure of the streets has provided the researcher a broad data collecting opportunity, and consequently this provides a more reliable research.

\section{Procedure}

A questionnaire developed by the researcher was handed out to the shop owners in Sincan in the $9^{\text {th }}$ May 2005 and to the shop owners in Çankaya in the $7^{\text {th }}$ May 2005. The reliability and the validity analyses of the questionnaire were done. In the reliability study, the questionnaire was handed out to a 50-person group of shop owners in a pilot project by 
multiplying the questionnaire by the researcher. After this pilot project, the unclear sides of the questions were modified and deficient options were appended to the questionnaire. For the validity analysis, no statistical procedure was done, only expert views were sought. The latest form of the questionnaire given after the pilot project was administered to everyone in the same way by the researcher. The questionnaire aims to measure the variables of sociocultural background of the shop owners.

\section{Instrumentation}

The numerical data gathered from the questionnaires have been put order after some statistical procedures. The data have been analyzed in SPSS Programme (Statistic Programme of Social Sciences). Two variables, Sincan and Çankaya, are proportioned to each other according to some criteria related to the research questions. The percentages and frequencies have been used as instruments of data analysis. These percentages and frequencies have been used to compare the two streets and these comparative data have also been tabulated in tables. Differences between two streets from the aspect of shop naming character have been presented as well. The statistical data have been demonstrated by tables in order to show the change.

\section{ANALYSIS and RESULTS}

Firstly, some general statistical data have been presented before coming to the answers of the main research questions. 'Çankaya' represents the 'Tunalı Hilmi Street' and 'Sincan' represent 'Vatan Street'. ' $F$ ' is used for 'frequency' and '\%' is used for 'percentage'.

\begin{tabular}{|l|l|l|}
\hline Region & Frequency & $\%$ \\
\hline Çankaya & 86 & 42,2 \\
\hline Sincan & 118 & 57,8 \\
\hline Total & 204 & 100 \\
\hline
\end{tabular}

Table 1: The dispersion of the subjects

Table 1 shows the participant dispersion of the two regions in the research. 118 shop owners have participated into the research due to the density of the work-places in Vatan Street in Sincan while 86 shop owners have participated in Tunalı Hilmi Street .

\begin{tabular}{|l|l|l|}
\hline Gender & Frequency & $\%$ \\
\hline Female & 45 & 21,1 \\
\hline Male & 159 & 77,9 \\
\hline Total & 204 & 100 \\
\hline
\end{tabular}

Table 2: The dispersion of the genders of the participants 
Table 2 demonstrates that the majority of the shop owners were male with 159 shop owners within total and the percentage of male participants is also high, $77,9 \%$ within total. The frequency of female shop owners is lower than male ones, 45 which equals to $21,1 \%$ within total.

\begin{tabular}{|l|l|l|}
\hline Origin & Frequency & $\%$ \\
\hline Turkish & 145 & 71,1 \\
\hline Foreign origin & 38 & 18,6 \\
\hline Mixed & 10 & 4,9 \\
\hline Meaningless & 11 & 5,4 \\
\hline Total & 204 & 100 \\
\hline
\end{tabular}

Table 3: Origins of the names

As can be seen from the Table 3, 145 of the 204 shop names are made of Turkish words which equals to $71,1 \%$ within total while the 38 of the 204 names are of foreign origin that equals to $18,6 \%$ within total. The percentage of the mixed* names is $4,9 \%$ with 10 names among 204 names while meaningless** names proportion is 5,4\% with 11 names within total.

*'Mixed' refers to the names which consist of both Turkish origin and foreign origin such as 'Mithat Collection', 'Cities Kuaför'

**'Meaningless' refers to the ones which consist of such names as 'papsi', 'duros' and the abbreviations.

3.1

By taking into account the answers to the first question of the questionnaire, the chart below has been prepared as an answer to the first research question, which is 'In the preference of the shop names, is the place of the shop name effective?',

\begin{tabular}{|c|c|c|c|c|c|c|c|c|c|}
\hline Region & \multicolumn{8}{|c|}{ Type of the name } & TOTAL \\
\hline & \multicolumn{2}{|c|}{ Turkish } & \multicolumn{2}{|c|}{ Foreign } & \multicolumn{2}{|c|}{ Mixed } & \multicolumn{2}{|c|}{ Meaningless } & \\
\hline Çankaya & $\mathrm{F}$ & $\%$ & $\mathrm{~F}$ & $\%$ & $\mathrm{~F}$ & $\%$ & $\mathrm{~F}$ & $\%$ & 86 \\
\hline & 35 & 40,7 & 35 & 40,7 & 8 & 4,2 & 8 & 4,6 & \\
\hline Sincan & 110 & 93,2 & 3 & 2,5 & 2 & 1,7 & 3 & 2,5 & 118 \\
\hline Total & 145 & 71,1 & 38 & 18,6 & 10 & 4,9 & 11 & 5,4 & 204 \\
\hline
\end{tabular}

Table 4: The relation between region- types of name 
The most interesting feature observed on the chart is the difference between the percentages of the Turkish words' usage in signs in two regions. In Çankaya 35 work-places have been named in Turkish which equals to $40,7 \%$ of the total names in this region. In Sincan this percentage is $93,2 \%$ with 110 Turkish names among 118 shop names in this region. Another finding about this figure is that the proportion of the foreign language usage in these streets is different from each other. In Çankaya 35 shops give foreign-origin names to their work-places, the ratio of which is $40,7 \%$ within total names in this region, while the proportion of foreign-origin words used in shop names in Sincan is 1,7\% with 3 names among 118 in this region. So, it might be concluded that the region/the geographical location of the shop is effective on the preference of the shop names and it determines the origin of the name of the shop whether it is foreign or not.

\section{2}

In order to answer the second research question 'In the preference of the shop names, is the educational background of the shop owners effective?' the chart below has been prepared from the statistics of the data collected from the fifth question of the questionnaire:

\begin{tabular}{|c|c|c|c|c|c|c|c|}
\hline \multirow{3}{*}{$\begin{array}{l}\text { Region } \\
\text { Çankaya }\end{array}$} & \multicolumn{6}{|c|}{ Educational Background of Subjects } & TOTAL \\
\hline & \multicolumn{2}{|c|}{$\begin{array}{l}\text { Primary/Secondary } \\
\text { School }\end{array}$} & \multicolumn{2}{|c|}{ High School } & \multicolumn{2}{|c|}{ University } & \\
\hline & $\mathrm{F}$ & $\%$ & $\mathrm{~F}$ & $\%$ & $\mathrm{~F}$ & $\%$ & 86 \\
\hline & 18 & 20,9 & 21 & 24,4 & 47 & 54,7 & \\
\hline Sincan & 42 & 35,6 & 59 & 50,0 & 17 & 14,4 & 118 \\
\hline Total & 60 & 29,4 & 80 & 39,2 & 64 & 31,4 & 204 \\
\hline
\end{tabular}

Table 5: The educational background of the shop owners

In Çankaya, 47 of the shop owners graduated from any university which constitutes $54,7 \%$ of the total shop owners. The number of the shop owners who did not graduate from a university is 39 among 86 shop owners which equals to $25,3 \%$ within total shop owners in Çankaya. However the case is vice versa in Sincan. The number of the shop owners who graduated from a university is 17 which constitutes $14,4 \%$ while the total number of shop owners who graduated from primary school, secondary school and high school is 101, which equals to $85,6 \%$ of the total shop owners in Sincan. Although this chart does not directly give answer to the research question, it may be inferred from the statistics that the shop owners in Sincan who have lower educational background have preferred Turkish names for their shops while the shop owners in Çankaya who have higher educational background have preferred foreign origin names for their work-places. That is, parallel to the region of the shop, as one moves from one educational background to another he/she is likely to come across different preferences of names. 
3.3

\begin{tabular}{|l|l|l|l|l|l|}
\hline \multirow{2}{*}{ Region } & \multicolumn{4}{l}{ The gender of the shop owners } & TOTAL \\
\cline { 2 - 6 } & Female & \multicolumn{2}{l|}{ Male } & \\
\hline \multirow{2}{*}{ Çankaya } & F & $\%$ & F & $\%$ & 86 \\
\cline { 2 - 6 } & 23 & 26,7 & 63 & 73,3 & \\
\hline Sincan & 22 & 18,6 & 96 & 81,4 & 118 \\
\hline Total & 445 & 22,1 & 159 & 77,9 & 204 \\
\hline
\end{tabular}

Table 6: The dispersion in the regions according to gender of the shop owners

Table 6 shows the percentage dispersion of the shop owners according to gender. As can be recognized from the chart, $81.4 \%$ of shop owners in Sincan is male, the frequency of which is 96 in 118 shop owners, while the percentage of male shop owners is $73.3 \%$ with 63 shop owners within total in Çankaya. It might be inferred that this high proportion of male population in two regions shows different characteristics in the naming process. That is, male shop owners who constitute $81,4 \%$ of the total population in Sincan gave Turkish names to their shops. On the other hand, in Çankaya, it is difficult to draw the same certain conclusion because the proportions of foreign-origin names and Turkish names are equal, though there is an enormous difference between genders of the shop owners. In the same way, the Table 7 below presents how the kind or characteristics of names change according to gender. It is seen that both genders give surnames to their work-places as names most frequently and randomly given names come in second place in the name preference for shops. As a result gender is not seen so effective as other social factors.

\begin{tabular}{|l|l|l|l|l|l|l|l|l|}
\hline Gender & \multicolumn{6}{|l|}{ The character of the job name } \\
& $\begin{array}{l}\text { Proper } \\
\text { name }\end{array}$ & Surname & $\begin{array}{l}\text { Given at } \\
\text { random }\end{array}$ & $\begin{array}{l}\text { Trade } \\
\text { mark }\end{array}$ & $\begin{array}{l}\text { Abbrevi } \\
\text { ation }\end{array}$ & $\begin{array}{l}\text { Sounds } \\
\text { good }\end{array}$ & Others & TOTAL \\
\hline Fermale & F \& $\%$ & F \& $\%$ & F \& $\%$ & F \& $\%$ & F \& $\%$ & F \& $\%$ & F \& $\%$ & 45 \\
\cline { 2 - 9 } & 0 & 12 & 10 & 2 & 1 & 3 & 17 & \\
& $0,0 \%$ & $26,7 \%$ & $22,2 \%$ & $4,4 \%$ & $2,2 \%$ & $6,7 \%$ & $37,8 \%$ & \\
\hline Male & 1 & 37 & 32 & 9 & 21 & 7 & 52 & 159 \\
& $0,6 \%$ & $23,3 \%$ & $20,1 \%$ & $5,7 \%$ & $13,2 \%$ & $4,4 \%$ & $32,7 \%$ & \\
\hline Fermale & 1 & 49 & 42 & 11 & 22 & 10 & 69 & 204 \\
& $100 \%$ & $24,0 \%$ & $20,6 \%$ & $5,4 \%$ & $10,8 \%$ & $4,9 \%$ & $33,8 \%$ & \\
\hline
\end{tabular}

Table 7: The relation between gender and the type of the job 


\section{4}

As an answer to the fourth question of the research, the researcher found out that the influence is mostly at the lexical level. There are a lot of high-frequency words in Turkish which are taken from European languages, especially from English. People adopted these words and become so familiar that they even do not regard them as foreign; for instance, telekom, vitamin, cafe etc. A lot of foreign-origin words have directly been taken (no change in pronunciation): Green, Line, Punica,Club, Anatolia, Bazaar, and Concept. In some words of the names which have foreign origin, phonological change in the original names has been observed. There is a tendency to adapt foreign items to Turkish phonology.

\begin{tabular}{|l|l|}
\hline English & Turkish \\
\hline Vocal & Vokal \\
\hline Flash & Flaş \\
\hline Boutique & Butik \\
\hline Dolphin & Dolfin \\
\hline Creation & Kreasyon \\
\hline Optic & Optik \\
\hline
\end{tabular}

Lastly, in a few names there is also seen a syntactic influence of English, especially in word order of the adjectival phrases. In English the adjectives which give information about the job or position of people, the word which informs about the job comes first, and then the name of the person comes (Teacher Mrs Brown, Doctor John). However, in Turkish which is called 'unvan sıfatı' comes after the name of the person (Mehmet Öğretmen, Ali Doktor). In such names as 'Eczane Seville', 'Kuaför Mithat', 'Kuaför Burhan' etc., this kind of influence is observed. The shop owners have their shop names fit the structure of English.

\section{DISCUSSION}

Upon observing the increasing amount of foreign words in work-place signs, the reasons of this situation were worth researching. The reasons of the case and the extent of the foreign influence in shop signs were researched in the light of research questions related with the variables of the region of the shop, educational background and gender of the shop owner and the level of the foreign influence (syntactic, phonological and lexical). A questionnaire was used in this survey-type research. It was applied 204 shop owners in total in two regions, Sincan and Çankaya; 118 shops in Vatan Street in Sincan and in 86 Tunalı Hilmi Street in Çankaya. For the first research question, the statistics which are showed in detail in data 
analysis part have demonstrated that the region of the shop determines the origin of the shop name. Since Turkish names are more frequently used in shop signs in Sincan, while foreign origin names together with mixed origin names are more frequently used in Çankaya. In second question was asked to search the effect of educational background on shop naming. As understood from the statistics, this variable is also effective on the naming process when compared to the proportions of the educational background of the shop owners and origin of the names that are more frequently used in shop signs in two regions. For the third research question asked to research the gender effect on the naming process, the statistical results have shown that the gender is not so effective as expected. Fourth research question was related with the level of the foreign influence on shop signs. It has been inferred from the replies given to questionnaires' first question that the influence is mostly on lexical level, since there are direct lexical transfers, 'borrowings', from English and French. Some of these words have been used as words of mother tongue recently, since they are adopted as native words.

The researcher also inferred that the selection of shop names' origin show difference according to the group of the customer which the region serve. Because Çankaya serves a higher educated and higher incomed customer group, and also this region is more densely populated by the foreign residents and mostly visited by upper class customers, while Sincan serves a lower educated and lower educated customer group. So they want to take the interest of the group they want to reach by giving foreign or Turkish origin names to the place of the shop.

In short, it is noted that foreign elements do not infiltrate another language haphazardly. Individual words are taken over easily and frequently. Once one feature has been brought in, it prepares the language for the next so on. Overall, then borrowing or transferring does not suddenly disrupt the basic structure of a language. Foreign elements make use of existing tendencies and commonly accelerate changes which are already underway, to illustrate, the situation of house with ill-fitting windows. If rain beats against the windows, it does not normally break the window or pass through solid panes of glass. It simply infiltrates the cracks which are already there. If the rain causes extensive dry rot, we could perhaps say that in a superficial sense the rain 'caused' the building to change structurally. But a deeper and more revealing analysis would ask how and why the rain was able to get in the window in the first place (Aitchison, 1991)

In this study it has been dealt with the reason of the frequently use of foreign origin words in work-place signs which may be a reflection of foreign influence on Turkish. To conclude, the changes in the tendency of the naming process are not done at random, yet some social factors are effective as explained above. 
Due to some reasons, researcher could not reach 31 shop owners in Çankaya which limit the data gathered from this region to 86 shop owners in Çankaya, consequently this narrowed the researcher's study field. This study is limited two streets representing two different regions which have different characteristics. The analysis field of the research may be enlarged to Ankara province. This study has only dealt with the influence of western languages in Turkish. Another study may be done about the pure Turkish words used in shop signs. Since the Arabic and Persian origin words have been accepted as Turkish words as a result of those kinds of words' being melted in Turkish basket (Özyıldırım, 2001).

\section{BIBLIOGRAPHY}

Aitchison, Jean. 1991. Language Change: Progress or Decay? . Malta: Cambridge University Press, ss 3-4, 105- 123

Akalın, Şükrü. 2000 Dil Kirliliği: Kebapçı, "Kebapchi” oldu. Hürriyet. 17 Aralık 2000. 20 Nisan 2005.

Aydoğan, Bedri. 1999. Arı Sineması Neden Cinema Arıplex Olur? Çağdaş Türk Dili Dergisi. sayı 131. Ankara: Kurtuluş Basımevi

Aydoğan, Bedri. 2001. Türkçe'ye Giren Yabancı Sözcükler ve Otel Adları. Türk Dili ve Edebiyat Dergisi. say1 596. Ankara: Ankara Üniversitesi Basımevi

Biber, Douglas, Edward Finegan. 1994. Sociolinguistic Perspectives on Register. Newyork: Oxford University Press

Doğan, İsmail. 1999. Sokaktaki Yabancı İşyeri İsimlerine Yansıyan Kültürel Eğilimler. İstanbul: Sistem Yayıncilik

Duman, Derya. 2002. Türk Toplumunda Anne ve Babaların Eğitim Düzeylerine Bağlı Olarak Ad Verme Davranışları. XVI. Dil Bilim Kurultayı Bildirileri: 23- 24 Mayıs 2002. Ankara: Hacettepe Üniversitesi Yayınları

König,Güray. 1991. Değişen Toplumda Dil. A.Ü Dil Öğretim Dergisi. Sayı 3. Ankara: A. Ü Yayınları

Osam, Necdet. 1997. Dil Kirlenmesine Sayısal Bir Yaklaşım. Dil Devriminden Bu Yana Türkçe'nin Görünümü. Ankara: Dil Derneği Yayınları, ss 59-67

Özyıldırım,Işı1. 2001. İşyeri levhaları:Isşlevsel Bir Yaklaşım. A.Ü. Dil Dergisi sayı 103, Ankara: A. Ü Yayınları

Wray, Allison, Kate Trott, Ailen Bloomer, Shirley Reah, Chris Butle.1998. Projects in Linguistics: A Practical Guide to Researching Language. London: Arnold Publishers: 88

Yurttaş, Hüseyin. 2005. Dönemler, Toplumsal Değişim ve Kişi Adları. Çağdaş Türk Dili Dergisi. sayı 205. Ankara: Demircioğlu Matbaacıllk

Yüce, İlhan. 2000. Dilimizin Bugünkü Durumu. Çağdaş Türk Dili Dergisi. Sayı 144. Ankara: Kurtuluş Basımevi.

$<$ http://arşiv.hurriyetim.com.tr/hur/turk/00/12/17/yasam/15yas.htm> 